\title{
Discussion on Dualism in Legal Status of State-run Universities in China
}

\author{
Mei Liu \\ Kunming University \\ Kunming, China
}

\begin{abstract}
Legal status of universities is an important content in studies on theories of educational law. A university is a major part of legal relation in education, so the legal status of universities is highly stressed in theories of educational law. This article starts with theories and status quo of legal status of universities in China, analyzes problems existing in the legal status of universities so that the universities are defined to be dualistic namely being civil subject and administrative subject.
\end{abstract}

Keywords-universities; legal status; civil subject; administrative subject

\section{INTRODUCTION}

As an educational institution, the university is an agent and core to establish connection between teachers, students and their guardians, and the studies on laws and theories relative to universities are directly related to teachers, students and their guardians. Legal status of universities refers to a status of universities which act as corporate or legal subject, it is a unity of rights and obligations of a university. A lot of disputes relative to universities often fail to be well solved legally due to the vague status and vacancy in laws. Especially there are more and more lawsuits between universities and students, due to the lack of legal rules to restrain actions of universities, the parties concerned and judges both have their brains racked in order to select forms of actions under the existing the lawsuit system where civil actions are separated from administrative litigation.

During juridical practices, among judgments, it is found that universities are defined by administrative subjects which grant rights. In the case where Tian Yong filed a lawsuit against University of Science \& Technology Beijing which refused to issue diploma and license of certificate to him, the court said, currently though some institutions and social organizations have no qualifications of administrative organs, yet they are approved by laws to exercise certain executive power. The relations the institutions and relative persons of management are not equal civil relations but a special relation of administrative management. And the disputes arising between them due to the administration do not belong to civil actions but administrative litigation... In order to protect the legal rights and benefits of relative persons of management, it needs to supervise the institutions and social organizations which should legally execute the executive power granted by the state, if they are defendants in administrative proceedings, administrative procedure law shall be adopted to solve the administrative disputes between them and relative persons of management, which will do good to solve social conflicts and maintain the social stability ${ }^{1}$.

\section{DEFINITION OF DEFECTS RELATIVE TO THE LEGAL} STATUS OF STATE-RUN UNIVERSITIES IN EXISTING LAWS IN THE COUNTRY

\section{A. Legal Status and Defects of State-Run Universities}

Article 30 of Higher Education Law of the People's Republic of China (hereinafter referred to the Education Law) provides: An institution of higher learning obtains the qualification of a legal entity as of the date of approval for its establishment. The legal entity here is sourced from General Principles of the Civil Law of the People's Republic of china (hereinafter referred to the General Principles of the Civil Law). In the General Principles of the Civil Law, the legal entity includes business entity, organ, institutional legal person and corporation. The State-Run universities belong to institutional legal person. In social practices, the State-Run universities in the country are defined as public institutions. The public institutions refer to social organizations which are in the leadership of state administrative organs, having no income from production, relevant costs are paid by the treasury, they execute no economic accounting and provide non-material production and labor services. With the development of socialization, the public welfare of public institutions has been weakened gradually, which has become an organization to perform state functions. As public institutions, the legal status of State-Run universities in the country are special to some degree, with the industrialization of logistics in universities, as far as accommodations and goods buys and sales, the status of civil subjects of State-Run universities are becoming more and more prominent. In accordance with Article 42-4 and Article 81 of the Educational Law, the colleges which violate students' legal rights and benefits in person, property and so on shall bear responsibilities for civil compensation. But it is a one-sided view if the university is only taken as a public institution with legal status of general civil subject. For with the above understanding only, it will be difficult to interpret why the universities own special administration privileges over students such as independent establishment of university rules, disciplines, rights to grant diploma and license and disciplinary treatment to students and so on. 


\section{Double Legal Status OF Civil SubJeCT AND ADMINISTRATIVE SUBJECT OF STATE-RUN UNIVERSITIES IN THE COUNTRY}

\section{A. Qualification of Civil Subject of State-Run Universities}

Article 31 of Higher Education Law of the People's Republic of China provides that an institution of higher learning obtains the qualification of a legal entity as of the date of approval for its establishment. As a legal entity, the university owns all characteristics shared by legal entities, including, I. The university is a social organization, which is a key point to separate it from other natural organizations. II. The university owns civil rights and civil competence.

First, the university is an independent organization, which means (1) The qualification of civil subject of the university is independent of that of natural persons (legal persons) such as teaches and students, and that some die or quit will not influence the existence of the university as a legal entity; (2) The organization of the university as a legal entity does not rely on other units or organization for existence.

Second, the universities own independent properties, which mean all properties that the legal entity owns or manages, independent of other properties of investors. For example, the properties of state-owned enterprises and state organs belong to other properties independent of the treasury or other ones. As for the independent properties of the universities, though Article 31-3 of the Educational Law provides "The state-owned properties of universities are possessed by the state", yet the ownership shall not influence the independence of the properties, for the ownership of properties of official organs as legal entities is also owned by the state, yet the official organs enjoy independent properties by law, so do the universities. Therefore, the independent properties of universities shall include all belongings that the universities own or are approved to use or manage, which are independent of other properties of the state, but occupied, managed and used independently by the universities by law.

Third, the universities can bear civil legal liabilities independently, with the independent organization and properties owned, the universities can carry out civil activities independently and bear civil rights and obligations independently. If the universities violate civil obligations, which damage other people or organizations, the universities shall bear independent civil liabilities, besides, the competent departments or state (investors) shall not bear joint responsibilities.

\section{B. Qualification of Administrative Subject of Universities}

Administrative subject refers to an organization which owns state executive power and executes it in the name of its own, able to independently bear relevant legal responsibilities. 2 Based on this concept, in order to judge whether an organization is an administrative subject, three conditions shall be met: first, whether it owns state executive power; second, whether it executes the executive power in the name of its own; third, whether it bears legal responsibilities independently.
First, the university is a social organization which owns state executive power.

Whether owning state executive power or not is a decisive condition for an organization to become an administrative subject. The right of education is a state power and a part of state executive power. Seen from the constitution, the right of education has three forms: (1) Decision-making right on educational policies; (2) Administrative management on education; (3) Enforcement rights of teaching activities, with the rights owned, some institutions (especially schools) and personnel (teachers) disseminate knowledge and skills to students in a certain form, the rights are a social right owned by schools and teachers. Article 28 of the Educational Law grants 9 rights to schools and other educational institutions, it is rights that the law grants but not power, however, the rights have some nature of (administrative) power. For example, the "enrollment right" in Item 3; the "students status management and punishment rights" (mainly refer to school expulsion) Item 4; the right of granting graduation certificates (including diploma and degree certificate) in Item 5 , all of these have natures of administrative power. Since the state educational right is a part of state administrative power, so the universities have qualification to execute the state executive power.

Second, the university is a social organization which can execute the executive power in the name of its own.

To execute the executive power in the name of its own means that within the legal scope, make decisions according to judgment of its own and guarantee the implementation of the decision with the obligations of its own, which is a major standard to judge whether an organization is an administrative subject. Since the establishment date of a university, it is granted qualification and capabilities to carry out teaching activities, and the educational law and higher educational law grant universities independent management inside and student enrollment outside, rights to manage student status and issuing of graduation certificates and so on When executing the rights the universities just do that in the name of the universities, but not the university investors. Though the universities execute the educational rights (through specific work as teaching activities) by the internal organization, yet it is just a functional arrangement in the universities, the internal departments have no rights to issue files and enroll students in the name of their own. The student enrollment and student status management, issuing of graduation certificates and so on have to be done in the name of the universities.

Finally, the universities are a social organization which can bear legal responsibilities independently.

Whether to bear independent legal responsibilities or not is a key condition for an organization to become an administrative subject. During the teaching activities, if is done out of the rights scope of the educational law and higher educational law or fails to fulfill obligations stated in the educational law and higher educational law, relevant legal responsibilities shall be borne independently by the universities concerned. Article 66 of the higher educational 
law provides, Penalties shall be imposed pursuant to the relevant provisions of the Education Law for activities of higher education in violation of the provisions of the Education Law. If universities collect fees and fail to expose the fee-related items, which violate state regulations, according to the order of administrative departments, they have to repay all fees, and those who are responsible for the results shall be punished with administrative sanction. Confiscation of illegal gains is a penalty to the universities which, but not the departments which collect the fees, have to bear responsibilities independently. The relation between universities and departments inside is to authorize and to be authorized

Acting as administrative subjects, the universities are limited to specific occasions. Administrative institutions are general administrative subjects, but the basic nature of a university is a legal entity, therefore, universities authorized by state laws can execute the state administrative power or public management power, as legal entity, the universities can bear the corresponding legal responsibilities independently, which comply with requirements of laws and regulations. Therefore, the universities own the status of administrative subject, only when they execute the authorized functions, can they own the qualification of administrative subject.

\section{CONCLUSION}

Based on the analysis mentioned above, we can find that the universities have civil and administrative nature, which is a complex entity. On the one hand, the universities, acting as independent civil subject, can enjoy civil rights and bear civil obligations; on the other hand, the universities when authorized by laws and regulations, own the status of administrative subject and execute the executive power according to laws.

\section{REFERENCES}

[1] Gazette of the Supreme People's Court , 1999, Issue. 4

[2] Edited by Luo Haocai, Administrative Law (M). Beijing: Peking University Press, 1996, Ver. 1, 48. 